\title{
Thalidomide-Dexamethasone Regimen
}

National Cancer Institute

\section{Source}

National Cancer Institute. Thalidomide-Dexamethasone Regimen. NCI Thesaurus. Code C63499.

A regimen consisting of thalidomide and dexamethasone used for the treatment for plasma cell myeloma. 